\title{
Communication
}

[Comunicação]

\section{Efficacy of cypermethrin on the control of Struthiolipeurus spp. (PHTHIRAPTERA: Philopteridae) in ostrich}

[Eficácia da cipermetrina no controle de Struthiolipeurus spp. (PHTHIRAPTERA: PHILOPTERIDAE) em avestruz]

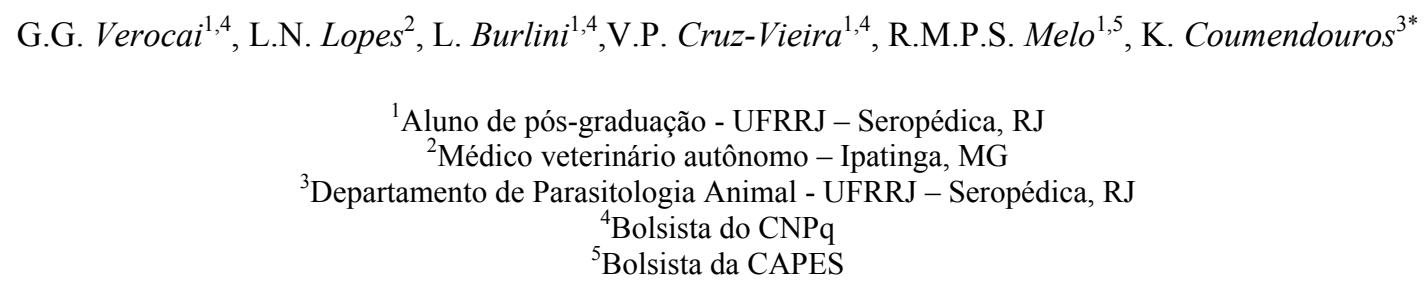

Ostrich farming, despite its recent introduction in Brazil, is gaining importance as commercial activity for the production of high quality meat, feathers, and leather, amongst other products.

Many studies concerning production, reproduction, and every kind of diseases in ostrich have being carried out throughout the world. Among several diseases, the parasitosis have been considered as an important threat to the productivity; therefore, appropriated control measures should be implemented (Ponce-Gordo et al., 2002; Cooper, 2005). The most common ectoparasites described in ostrich in Brazil, are mites, such as Struthiopterolichus bicaudatus and S. sculpturatus (Faccini et al., 2006; Mattos $\mathrm{Jr}$ et al., 2007); and lice from the genus Struthiolipeurus (Phthiraptera: Philopteridae), which were reported in commercial farms from States of different geografic Regions (Fagundes et al., 2004; Ribeiro et al., 2004; Silva et al., 2004). During high intensity infestations, the fwols may show from much damaged plumage to heavy loss of feathers, probably because of intense pruritus and self-pecking (Huchzermeyer, 1999).

These arthropods can cause damage to the feathers and skin of infected ostrich, either directly by the parasites or indirectly by excessive preening or rubbing of skin, leading to diminished economic value of feathers and hide (Black, 2001). In addition, Cooper (2005) suggested that the ectoparasitism causes stress and indirectly predisposes fowls to secondary infections and gastrointestinal disorders. Effective quarantine procedures can prevent the entry of these parasites in the property. But, in the event of significant infestation, routine strategic treatment regimes often based on ivermectin and/or topical insecticide treatment should be undertaken (Cooper, 2001).

Cypermethrin, like other pyrethroids, has a wide spectrum of insecticidal potency, vertebrate toxicity, and environmental stability. The primary effect of pyrethroids is to slow the closing of the sodium activation gate in nerve cells. All pyrethroids have essentially the same basic mechanism of action on voltage-dependent sodium channels, but they differ in the magnitude of effect. It is classified as a Type II pyrethroid and acts inhibiting the GABA receptor presented at the muscular tissue of insects, which has higher toxicity than Type I pyrethroids (Valentine, 1990).

Due to its practical form of application, commercialization, and cost, it is widely employed for controlling ectoparasites of livestock animals, like lice in ruminants (Rothwell et al., 1999) and in birds (Salisch,

Recebido em 11 de março de 2008

Aceito em 2 de setembro de 2008

* Autor para correspondência (corresponding author)

E-mail: katherinac@ufrrj.br 
1989). The goal of the current study was to evaluate the efficacy of a $15 \%$ cypermethrin solution, in the dilution of $1 \mathrm{ml} / 1$, for the control of the lice Struthiolipeurus spp. in ostrich.

For this study, 240 breeder ostrich aging from 12 to 24-month-old, raised in the same farm, located in Caratinga Municipality, MG, Southeastern Brazil, were visually examined for the parasitism of Struthiolipeurus spp. after being properly contained. Out of these, 168 (70\%) were infested with lice.

The parasitism degree was always individually evaluated by the same investigator, by the method of visual examination described by Clayton and Drown (2001). Twelve birds were considered heavily infested, 128 with moderate infestation, 24 with low infestation, and the remaining four with very low parasitism. Some specimens were collected, fixed in $70 \%$ ethanol, and were taken to the laboratory and mounted in Hoyer's medium to confirm the genus diagnosis according to Mey (1998).

All the birds, including the non-parasitized ones, were treated by spraying a $15 \%$ cypermethrin solution $^{1}$, in the dilution of $1 \mathrm{ml} / 1$, with the aid of a costal sprayer and appropriated personal protection. Treated animals were reexamined on days 7,14 , and 21 after the treatment, for the presence of lice.

All the ostrich were negative for the presence of Struthiolipeurus spp. on the days of observation, after the topical treatment with cypermethrin $15 \%$, demonstrating $100 \%$ efficacy for the control of this genus of lice.

No drug-related adverse effects were observed on any of the treated ostrich. In the literature, studies concerning lice control in ostrich, in Brazil, were not found. Permin and Hansen (1998) suggested treatments with powder formulations for the control of avian lice, such as malathion 4 to $5 \%$, permethrin $0.25 \%$, and carbaryl $5 \%$. On the other hand, malathion $0.5 \%$, permethrin $0.05 \%$, and tetrachlorvinphos $0.5 \%$ can be used by spraying.

Some authors had employed a powder formulation containing $1-5 \%$ malathion, subcutaneous or oral flumethrin, and ivermectin at $0.2 \mathrm{mg} / \mathrm{kg}$, as an usual treatment against Struthiolipeurus spp. Infestations. However, the efficacy levels were not specified (Huchzermeyer, 1999). Cooper and El Doumani (2006), studying the presence of mites and lice in different types of ostrich wing feathers, also recommended treatment with 1-5\% malathion dusting powder, fortnightly. In South Africa, Van der Merwe et al. (2004) evaluated the efficacy of a $1 \%$ amitraz/cypermethrin formulation topically applied at $1 \mathrm{ml} / 10 \mathrm{~kg}$ body weight against $S$. struthionis, and, also, reached $100 \%$ of effectiveness.

The route of application employed in the forecited studies are considered less practical than in the present one, and the product was a pour-on formulation, which does not disperse well on ostrich. The treatment presented in the literature seems as effective as the control strategy evaluated in this study.

The use of $15 \%$ cypermethrin solution by spraying, in the dilution of $1 \mathrm{ml} / 1$, is recommended for the control of Struthiolipeurus spp. in ostrich.

Keywords: ostrich, Struthio camelus, lice, Struthiolipeurus spp., cypermethrin

\section{RESUMO}

Duzentos e quarenta avestruzes, com idades entre 12 e 24 meses, foram examinados quanto ao parasitismo por Struthiolipeurus spp. Destes, 168 apresentavam-se infestados por piolhos (70\%). Todas as aves foram tratadas com solução de cipermetrina a $15 \%$, na diluição de $1 \mathrm{ml} / \mathrm{l}$, por pulverização com auxílio de uma bomba costal. Os animais positivos foram reexaminados nos dias 7, 14 e 21 após o tratamento, e não foram mais encontrados piolhos. A cipermetrina apresentou $100 \%$ de eficácia no controle de piolhos do gênero Struthiolipeurus em avestruz.

Palavras-chave: avestruz, Struthio camelus, piolho, Struthiolipeurus spp., cipermetrina

${ }^{1}$ Cypermil Pulverização ${ }^{\circledR}$ - Ouro Fino - Ribeirão Preto, Brazil. 


\section{REFERENCES}

BLACK, D. Ostrich flock health. Semin. Avian Exotic Pet, v.10, p.117-130, 2001.

CLAYTON, D.H.; DROWN, D.M. Critical evaluation of five methods for quantifying chewing lice (Insecta: Phthiraptera). $J$. Parasitol., v.87, p.1291-1300, 2001.

COOPER, R.G. Ostrich (Struthio camelus var. domesticus) skin and leather: A review focused on Southern Africa. World's Poult. Sci. J., v.57, p.157-178, 2001.

COOPER, R.G. Bacterial, fungal and parasitic infections in the ostrich (Struthio camelus var. domesticus), Anim. Sci. J., v.76, p.97-106, 2005.

COOPER, R.G.; EL DOUMANI, H.A. The presence of quill mites (Gabucinia bicaudata) and lice (Struthiplipeurus struthionis) in ostrich wing feathers. J. S. Afr. Vet. Assoc., v.77, p.9-11, 2006.

FACCINI, J.L.H.; VEROCAI, G.G.; LOPES, L.N. et al. Ocurrence of Struthiopterolichus bicaudatus (Acari; Pterolichidae) in Southeastern Brazil. Arq. Bras. Med. Vet. Zootec., v.58, p.959-960, 2006.

FAGUNDES, T.F.; BATH, F.V.C.; SOLEIRO, C.A. et al. Inquérito preliminar sobre parasitas de avestruzes (Struthio camelus) de um criatório localizado no estado do Rio de Janeiro. Rev. Bras. Parasitol. Vet., v.13, p.368, 2004.

HUCHZERMEYER, F.W. Patología de avestruces y otras ratites. Madrid: Ediciones Mundi-Prensa, 1999. 284p.

MATTOS Jr, D.G.; AMARAL, J.A.; PORTO, M. et al. Registro de ácaros em avestruz no estado do Rio de Janeiro. Arq. Bras. Med. Vet. Zootec., v.59, p.536-538, 2007.

MEY, E. Zur taxonomie, lebensweise und parasitophyletischen evidenz der federlingsgattung Struthiolipeurus sensu lato (Insecta, Phthiraptera, Ischnocera). Mitt. Mus. Nat. Kd. Berl., Zool. Reihe, v.74, p.65-93, 1998.

PERMIN, A.; HANSEN, J.W. The Epidemiology, diagnosis and control of poultry parasites. Roma: FAO, 1998. 160p.

PONCE-GORDO F.; HERRERA S.; CASTRO A.T. Parasites from farmed ostriches (Struthio camelus) and rheas (Rhea americana) in Europe. Vet. Parasitol., v.107, p.137-160, 2002.

RIBEIRO, V.L.S.; RIBEIRO, M.M.; DALMAGRO, $M$. et al. Ocorrência de Struthiolipeurus struthionis (GERVAIS, 1844) (PHTHIRAPTERA: PHILOPTERIDAE) em Struthio camelus LINNAEUS, 1758 (STRUTHIONIFORMES: STRUTHIONIDAE) no Rio Grande do Sul, Brasil. Rev. Bras. Parasitol. Vet., v.13, p.332, 2004.

ROTHWELL, J.T.; HACKETT, K.C.; RIDLEY, I. et al. Therapeutic efficacy of zetacypermethrin pour-on for the treatment of biting and sucking lice in cattle under field conditions. Aust. Vet. J., v.77, p.255-258, 1999.

SALISCH, H. Recent developments in the chemotherapy of parasitic infections of poultry. World's Poult. Sci. J., v.45, p.115-124, 1989.

SILVA, A.L.A.; BOTÊLHO, M.C.N.; CAVALCANTI, M.D.B. et al. Parasitos de avestruz (Struthio camelus) em Pernambuco, Rev. Bras. Parasitol. Vet., v.13, p.370, 2004.

VALENTINE, W.M. Toxicology of selected pesticides, drugs and chemicals Pyrethrin and pyrethroid insecticides. Vet. Clin. N. Am.: Small. Anim. Pract., v.20, p.375-382, 1990.

VAN DER MERWE, J.S.; SMIT, F.J.; VAN SCHALKWYK, L. et al. The efficacy of an amitraz/cypermethirn pour-on applied topically against the lice of ostrich (Struthio camelus). $J$. S. Afr. Vet. Assoc., v.75, p.70-71, 2004. 